\title{
Kelola
}

\section{Evaluasi Program Indonesia Pintar dalam Peningkatan Akses Pendidikan di Sekolah Menengah Pertama}

\author{
Wirastiani Binti Yusup \\ Sekolah Tinggi Agama Kristen Negeri (STAKN) Palangka Raya \\ wirastiani94@gmail.com \\ Bambang Ismanto \\ Univeristas Kristen Satya Wacana \\ bambang.ismanto@staff.uksw.edu \\ Wasitohadi \\ Univeristas Kristen Satya Wacana \\ wasitohadi@staff.uksw.edu
}

\begin{abstract}
This study aimed to evaluate the design, installation, process, product, and analysis of benefits and costs of the implementation of the Program Indonesia Pintar (PIP) in Improving Access to Education in SMP Negeri 7 Salatiga. This research type is evaluative research using Discrepancy Evaluation Model. Data collection techniques used interviews, observations and document studies. Data analysis through: data collection, data reduction, data display, and conclusion. Data validation uses source triangulation and technique. The research results: (1) design components are formulated with reference to PIP Juknis in 2015 covering aspects of objectives, processes, human resources, facilities and infrastructure, (2) installation components there is still discrepancy between PIP implementation objectives with PIP objectives in junior State 7 Salatiga, (3) process components, planned programs are running in accordance with PIP Permendikbud, although in the implementation there are inhibiting factors, (4) product components, the objectives achieved are learners can buy school purposes, paying school administration fees (5) benefit and cost analysis components, PIP funding benefits are great for underprivileged learners, although PIP funds are still very poor in meeting the educational needs of learners each year.
\end{abstract}

Keywords: Discrepancy Evaluation Model, Program Evaluation, Program Indonesia Pintar (PIP)

\section{Article Info}

\section{PENDAHULUAN}

Pendidikan merupakan salah satu upaya yang ditempuh dalam membangun dan meningkatkan mutu Sumber Daya Manusia (SDM), karena pendidikan dianggap mampu menciptakan manusia yang produktif dalam memajukan suatu bangsa. Pembangunan pendidikan dianggap penting karena mampu memberi kontribusi signifikan dalam upaya mencapai kemajuan bangsa diberbagai bidang kehidupan. Oleh karena itu pendidikan menjadi hal yang sangat penting bagi manusia dan tidak boleh diabaikan terutama dalam menghadapi dunia yang penuh persaingan. Hal ini 
mengacu pada pemikiran Santoso, Sarjono dan Wafroturrohmah (2014: 3) bahwa pendidikan merupakan faktor penting dalam kehidupan maka arah pendidikan masa depan harus mampu memberikan jalan pemecahan masalah bagi pembangunan yakni tersedianya sumber daya insan yang berkualitas sehingga mampu mengantisipasi setiap perubahan yang terjadi secara cepat.

Salah satu kebijakan umum pembagunan nasional 2015-2019, adalah meningkatkan kualitas SDM yang adil melalui peningkatan akses pendidikan yang berkualitas di semua jenjang pendidikan khususnya bagi masyarakat miskin dan daerah tertinggal (Rencana Strategis Kemendikbud 2015-2019, 2015). Menyadari pentingnya pendidikan, pemerintah terus berupaya memenuhi hak setiap warga negara dalam memperoleh layanan pendidikan guna meningkatkan kualitas hidup bangsa Indonesia. Hal ini penting karena telah diamanatkan oleh pasal 31 Undang-Undang Dasar 1945 bahwa: "Pemerintah mengusahakan dan menyelenggarakan satu sistem pendidikan nasional yang meningkatkan keimanan dan ketaqwaan serta akhlak mulia dalam rangka mencerdaskan kehidupan bangsa, yang diatur dengan undang-undang" (ayat 3).

Berdasarkan ketentuan tersebut, dapat dipahami bahwa upaya pemerintah untuk melunasi janji kemerdekaaan dan kesungguhan melaksanakan amanat konstitusi terkait pendidikan semakin didukung oleh Undang-Undang. Visi pendidikan pun semakin jelas, sebagaimana yang diungkapkan dalam Undang-Undang Nomor 20 Tahun 2003 bahwa terwujudnya sistem pendidikan sebagai pranata sosial yang kuat dan berwibawa memberdayakan semua warga negara Indonesia berkembang menjadi manusia yang berkualitas, sehingga mampu menjawab tantangan zaman yang selalu berubah. Oleh karena itu setiap orang berhak mengembangkan diri melalui pemenuhan kebutuhan dasarnya, berhak memperoleh pendidikan dan manfaat dari ilmu pengetahuan dan teknologi, seni dan budaya, demi meningkatkan kualitas hidupnya dalam rangka menjadi masyarakat sejahtera. Pendidikan yang layak harus dapat diakses oleh setiap orang dengan tidak dibatasi oleh usia, tempat dan waktu, dengan menjamin keberpihakan kepada peserta didik yang memiliki hambatan fisik, mental, ekonomi, sosial, ataupun geografis.

Pemerintah telah berupaya

meningkatkan kualitas hidup bangsa Indonesia, melalui peningkatan kualitas pendidikan dengan Program Indonesia Pintar (PIP). Kepala Pusat Penilaian Pendidikan Balitbang (Kapuspendik Balitbang) mengatakan secara konsisten terjadi peningkatan cakupan sampling peserta didik Indonesia yaitu sebanyak 46 persen di tahun 2003 menjadi 53 persen di tahun 2006. Selanjutnya, angka tersebut naik ke 63,4 persen di tahun 2012, dan menjadi 68,2 persen di tahun 2015. Peningkatan cakupan sampling ini merupakan bukti capaian wajib belajar 9 tahun dan ekspansi menuju wajar 12 Tahun dalam pendidikan membuahkan hasil (Kemendikbud, 2016). Meskipun demikian, kualitas layanan pendidikan masih rendah karena dukungan fasilitas dan tenaga pendidik yang belum memadai di seluruh wilayah Indonesia, khususnya bagi daerah terpencil. Hal itu mengakibatkan jumlah siswa putus sekolah pada jenjang SD/MI, SMP/MTs, SMA/MA masih banyak. Pada tahun yang sama cukup banyak siswa SD/MI, SMP/MTs, SMA/MA yang tidak dapat melanjutkan pendidikan ke jenjang selanjutnya. Masalah putus sekolah menjadi masalah yang serius yang dihadapi oleh anak bangsa yang kurang mampu dan dapat mempengaruhi keberhasilan penuntasan Program Indonesia Pintar dalam meningkatkan akses pendidikan.

Berdasarkan data Badan Pusat Statistik Tahun 2014, tingkat kemiskinan di 
Kota Salatiga lebih rendah bila dibandingkan dengan Provinsi Jawa Tengah secara keseluruhan. Adapun angka kemiskinan dari tahun 2010-2014 dapat dilihat dalam tabel berikut:

Tabel 1 Angka Kemiskinan Kota Salatiga Tahun 2010-2014:

\begin{tabular}{ccccc}
\hline No & Tahun & Salatiga & Jawa Tengah & Nasional \\
\hline 1 & 2010 & 8,28 & 16,11 & 13,33 \\
\hline 2 & 2011 & 7,80 & 16,21 & 12,36 \\
\hline 3 & 2012 & 7,11 & 14,98 & 11,66 \\
\hline 4 & 2013 & 6,40 & 14,44 & 11,48 \\
\hline 5 & 2014 & 5,93 & 13,58 & 10,96 \\
\hline
\end{tabular}

Sumber: BPS Kota Salatiga, TNP2K

Adapun data kemiskinan tahun 2014 belum dapat diketahui dan masih menunggu hasil perhitungan kemiskinan makro dari BPS. Berdasarkan tabel 1 tersebut dapat diketahui bahwa secara umum angka kemiskinan makro di Kota Salatiga mengalami penurunan (RKPD Kota Salatiga, 2017).

Pelaksanaan program pembangunan pendidikan di Kota Salatiga pada tahun 2015 mendukung berkembangnya belajar mengajar diberbagai jenis dan jenjang pendidikan.
Pelayanan pendidikan telah menjangkau semua penduduk tanpa terkecuali. Capaian target indikator sasaran Urusan Pendidikan tercermin dari terealisasinya indikator kinerja kunci yang menunjukkan keberhasilan pembangunan melalui pelaksanaan program-program dan kegiatan-kegiatan dalam tahun 2015. Keberhasilan Pembangunan di Urusan Pendidikan dapat dilihat lebih rinci dari indikator kinerja pelayanan yang telah dicapai di tahun 2015 adalah sebagai berikut:

Tabel 2. APK dan APM Kota Salatiga Tahun 2014-2015

\begin{tabular}{cccccccccc}
\hline & & \multicolumn{4}{c}{$\mathbf{2 0 1 4}$} & \multicolumn{3}{c}{$\mathbf{2 0 1 5}$} \\
\cline { 3 - 10 } Jenjang & Sat & \multicolumn{2}{c}{ Target } & \multicolumn{2}{c}{ Realisasi } & \multicolumn{2}{c}{ Target } & \multicolumn{2}{c}{ Realisasi } \\
\cline { 3 - 10 } & & APK & APM & APK & APM & APK & APM & APK & APM \\
\hline SD/MI & $\%$ & 100 & 100 & 110 & 94,18 & 100 & 100 & 115,53 & 99,58 \\
\hline SMP/MTS & $\%$ & 100 & 100 & 114,95 & 81,98 & 100 & 99 & 125,43 & 84,70 \\
\hline SMA/MA/SMK & $\%$ & 100 & 100 & 138,81 & 95,11 & 100 & 100 & 159,07 & 112,16 \\
\hline \multicolumn{2}{l}{ Sumber: Dinas Pendidikan, Pemuda dan Olahraga (Disdikpora) Kota Salatiga }
\end{tabular}

Dari tabel di atas terlihat bahwa APK tahun 2015 pada jenjang SD/MI, SMP/MTS, SMA/MA/SMK mengalami peningkatan dibandingkan tahun 2015 yaitu sebesar 5,53\%, 10,48\%, dan 20,26\% (RKPD Salatiga Tahun 2017).

Secara keseluruhan tingkat pendidikan di Kota Salatiga sudah meningkat dari tahun sebelumnya. Angka Partisipasi Murni (APM) usia 7-12 di Kota Salatiga pada tahun 20,26\%. Terlihat pada jenjang pendidikan SMP/MTS masih tergolong rendah dibandingkan pada jenjang SD/MI dan SMA/MA/SMK Semakin tinggi jenjang pendidikan di Kota Salatiga, semakin rendah angka partisipasi murninya. Hal ini menggambarkan masih kurangnya partisipasi masyarakat untuk melanjutkan pendidikan ke jenjang pendidikan menengah pertama. Angka putus sekolah pada jenjang SMP/MTS mengalami peningkatan dari tahun tahun sebelumnya yaitu 0,2 menjadi 0,21 persen (Disdikpora Kota Salatiga, 2017).

Masalah ekonomi merupakan salah satu penyebab masih banyak anak usia sekolah yang tidak dapat bersekolah atau putus sekolah. Namun banyak faktor lain 
yang menjadi penyebab putus sekolah adalah ketersediaan akses dan fasilitas pendidikan yang memadai dan terjangkau. Hal ini sejalan dengan hasil penelitian Zahidy (2008) bahwa rendahnya tingkat perekonomian keluarga menjadi salah satu penghalang bagi peserta didik untuk menuntaskan proses pendidikan selama 9 Tahun.

Untuk mengurangi angka putus sekolah dan menarik anak yang putus sekolah, Pemerintah memberikan kesempatan seluasluasnya kepada masyarakat agar memperoleh layanan pendidikan, salah satunya melalui PIP. Hal ini sejalan dengan pendapat Astuti (2016) bahwa PIP memiliki peran yang sangat penting bagi dunia pendidikan. Pertama sebagai aksebilitas pendidikan membantu pemerataan dalam mengakses pendidikan sehingga peserta didik yang berasal dari keluarga yang kurang mampu dapat mengakses pendidikan.

Pada hakikatnya PIP merupakan penyempurnaan dari program Bantuan Siswa Miskin (BSM). Permendikbud Nomor 12 Tahun 2015 menjelaskan bahwa Program Indonesia Pintar merupakan pemberian bantuan tunai pendidikan bagi anak usia sekolah dari keluarga pemegang Kartu Keluarga Sejahtera (KKS), atau yang memenuhi kriteria sebagaimana ditetapkan sebelumnya yang ditandai dengan pemberian Kartu Indonesia Pintar (KIP) kepada anak usia sekolah dari keluarga kurang mampu pemilik KKS. Penerima KIP adalah anak usia 6 - 21 tahun yang bersekolah maupun tidak bersekolah, yang berasal dari keluarga penerima KKS atau yang memenuhi kriteria yang telah ditetapkan.

Rencana Pembangunan Jangka

Menengah Nasional (RPJMN 2015-2019) mendukung pencapaian agenda prioritas pembangunan kelima (Nawacita: 5) dengan meningkatkan kualitas hidup manusia dan masyarakat Indonesia, melalui PIP dengan sasaran di antaranya, (a) meningkatkan angka partisipasi pendidikan dasar dan pendidikan menengah, (b) menurunnya kesenjangan partisipasi pendidikan antar kelompok masyarakat terutama antara penduduk kaya dan miskin, antara penduduk laki-laki dan perempuan, (c) meningkatkan angka keberlanjutan pendidikan yang ditandai dengan menurunnya angka putus sekolah dan angka melanjutkan, (d) meningkatkan kesiapan siswa pendidikan menengah untuk memasuki pasar kerja atau melanjutkan ke jenjang pendidikan tinggi.

Dalam peningkatan kualitas pendidikan, akses pendidikan harus terus ditingkatkan agar semua kalangan dapat menikmati pendidikan menuju masyarakat yang sejahtera. Meskipun kebijakan desentralisasi dan otonomi pendidikan telah dilaksanakan, manajemen layanan pendidikan belum sepenuhnya efektif dan efisien. Oleh karena itu sasaran kebijakan dalam hal akses pendidikan, sangat perlu untuk ditingkatkan karena belum semua siswa yang kurang mampu dapat memperoleh pendidikan yang layak sebagaimana seharusnya yang diperoleh.

Kota Salatiga adalah salah satu Kota di Provinsi Jawa Tengah yang melaksanakan PIP. Berdasarkan studi pendahuluan yang dilakukan peneliti, diperoleh informasi bahwa SMP Negeri 7 Salatiga merupakan Sekolah Menengah Pertama di Kota Salatiga yang sudah menerima dan melaksanakan PIP sejak tahun 2015. Berdasarkan wawancara dengan kepala sekolah SMP Negeri 7 Salatiga, diketahui bahwa PIP merupakan program pemerintah yang dilaksanakan di seluruh Indonesia. Oleh karena itu, sangat penting untuk diteliti sebagai acuan dalam mengoptimalkan pelaksanaan PIP disetiap sekolah yang ada di Indonesia khususnya di SMP Negeri 7 Salatiga. Maka dari itu, peneliti tertarik untuk melakukan evaluasi terhadap PIP yang sudah berjalan sekitar 2 (dua) tahun.

Berdasarkan latar belakang masalah tersebut, penelitian ini bertujuan untuk mengevaluasi Pelaksanaan Program Indonesia 
Pintar dalam Peningkatan Akses Pendidikan di SMP Negeri 7 Salatiga menggunakan model Kesenjangan (Discrepancy Evaluation Model). Model tersebut sengaja dipilih karena model ini mampu mengidentifikasi kesenjangan di dalam pelaksanaan berdasarkan komponenkomponen yang ada. Hal itu sesuai dengan pendapat Arikunto dan Jabar (2010: 48) yang menyatakan bahwa Model Evaluasi Kesenjangan dikembangkan dengan memberi penekanan pada pandangan adanya kesenjangan di dalam pelaksanaan program. Selanjutnya Mulyatiningsih (2011: 114) menyatakan bahwa evaluasi program dilakukan dengan tujuan untuk: menunjukkan sumbangan program terhadap pencapaian tujuan organisasi. Hasil evaluasi penting untuk mengembangkan program yang sama di tempat lain; (2) mengambil keputusan tentang keberlanjutan sebuah program, apakah program perlu diteruskan, diperbaiki atau dihentikan.

Penelitian ini menggunakan model evaluasi kesenjangan yang dikembangkan oleh Provus. Boulmetis \& Dutwin (2017:84) menjelaskan bahwa model evaluasi kesenjangan dapat digunakan dalam melihat kesenjangan pada program secara menyeluruh. Model ini bukan untuk membuktikan sebab-akibat, namun untuk melihat kesesuaian antara yang diharapkan dengan yang terjadi. Kesesuaian program dapat dilihat melalui beberapa tahap antara lain:

(1) Desain, menganalisis kebutuhan dan merencanakan bagaimana program dirancang, kemudian dibandingkan dengan standar program;

(2) Instalasi, membandingkan standar program dengan yang akan dilaksanakan, dalam tahap ini evaluator akan membandingkan kesesuaian program yang sedang berjalan;

(3) Proses membadingkan perencanaan dengan apa yang sedang dicapai;
(4) Produk melihat hasil akhir yang telah dicapai;

(5) Analisis manfaat-biaya, membandingkan manfaat yang diperoleh dengan biaya yang dikeluarkan (John Boulmetis, 2017:86)

Sesuai dengan model yang hendak digunakan di atas, maka penelitian ini hendak mengevaluasi kesenjangan pada tahap desain, instalasi, proses, produk, dan analisis manfaat-biaya PIP di di SMP Negeri 7 Salatiga. Hasil penelitian ini diharapkan dapat memberi manfaat baik secara teoritis terhadap perkembangan ilmu pengetahuan manajemen pendidikan dan secara praktis bagi sekolah, orangtua, Dinas Pendidikan BAPPENAS, Kemenkeu, dan Kemendikbud..

\section{METODE PENELITIAN}

Penelitian ini merupakan penelitian kualitatif evaluatif dengan model Kesenjangan. Penelitian ini dilaksanakan di SMP Negeri 7 Salatiga. Subjek penelitian adalah Program Indonesia Pintar. Sumber data meliputi: Kepala Sekolah, Guru Bimbingan Konseling, Wakil Kurikulum Sarana dan Prasarana, Peserta didik dan Orangtua penerima PIP. Teknik pengumpulan data yang digunakan adalah wawancara, observasi dan studi dokumen. Beberapa tahapan yang dilakukan dalam analisis data penelitian ini yaitu: (1) pengumpulan data, (2) reduksi data, (3) display data, (3) kesimpulan. Uji validitas data yang digunakan dalam penelitian ini adalah triangulasi sumber dan triangulasi teknik.

\section{HASIL PENELITIAN DAN PEMBAHASAN}

\section{Hasil Penelitian}

1. Evaluasi Desain Program Indonesia Pintar

Pada tahap desain, peneliti menganalisis tentang perumusan tujuan, proses, sumber daya manusia dan sarana prasarana pelaksanaan PIP di SMP Negeri 7 Salatiga. berdasarkan hasil 
wawancara dan telaah dokumen yang dilakukan, tujuan pelaksanaan PIP adalah untuk membantu peserta didik memenuhi kebutuhan pendidikannya, sehingga tidak ada peserta didik yang putus sekolah karena kesulitan ekonomi. Proses pelaksanaan PIP dirumuskan dengan mengacu pada Juknis PIP. Sumber daya manusia yang diperlukan dalam pelaksanaan PIP adalah yang memiliki kompetensi dan sudah mengetahui tentang PIP. sarana dan prasarana yang diperlukan dalam pelaksanaan PIP adalah foto copy KIP, KK, KTP Orangtua dan Surat Keterangan dari Kepala Sekolah.

2. Evaluasi Instalasi Program Indonesia Pintar

Pada tahap ini, pihak sekolah merencanakan pelaksanaan PIP sesuai dengan Juknis yang telah dibuat oleh pemerintah. Perencanaan tersebut menekankan pada aspek tujuan, proses, sumber daya manusia, sarana dan prasarana yang diperlukan. Tujuan pelaksanaan PIP di SMP Negeri 7 Salatiga adalah untuk membantu peserta didik dalam memenuhi kebutuhan sekolah, khususnya yang tidak mampu dibiayai oleh orangtua akibat kesulitan ekonomi. Untuk mencapai tujuan yang ada, pelaskanaan PIP di SMP Negeri 7 dilaksanakan sesuai dengan mekanisme yang terdapat dalam Juknis, yaitu sosialiasi PIP kepada orangtua, prosedur pelaksanaan PIP, tahap pengusulan, penetapan penerima oleh Direktorat teknis, penyaluran dana oleh Bank BRI, pengambilan dana oleh peserta didik secara tunai. Monitoring pelaksanaan PIP dilakukan oleh Dinas Pendidikan Kota Salaiga. Pelaksanaan PIP di SMP Negeri 7 ditangani khusus oleh tim pelaksana berdasarkan pembagian tugasnya masing-masing. Pengadaan sarana dan prasarana yang diperlukan, tim pelaksana meminta peserta didik mengumpulkan data seperti, foto copy KIP, KK, KTP orangtua dan Surat Keterangan dari Kepala Sekolah.

3. Evaluasi Proses Program Indonesia Pintar.
Pelaksanaan PIP di SMP Negeri 7 Salatiga sudah berjalan sesuai dengan program yang direncanakan. Proses pelaksanaan PIP sudah sesuai dengan mekanisme yang terdapat dalam Juknis. Tim pelaksana PIP mensosialisasikan PIP kepada peserta didik dan orangtua, selain itu tim pelaksana juga melakukan seleseksi kepada peserta didik yang layak untuk diusulkan menerima dana PIP. Monitoring dan evaluasi dilakukan oleh Kepala Sekolah dan Dinas Pendidikan melalui laporan pertanggungjawaban pelaksanaan PIP. Adapun faktor penghambat dalam pelaksanaan PIP adalah pengumpulan dokumen terkait PIP membutuhkan waktu yang cukup lama, tim pelaksana kesulitan mengontrol pemanfaatan dana PIP, kesulitan mencari peserta didik yang masih menerima PIP, namun sudah lulus dari SMP Negeri 7 Salatiga. Sedangkan faktor pendukung adalah kompetensi yang dimiliki oleh Tim pelaksana membantu pelaksanaan PIP mencapai tujuan yang diharapkan, pemanfaatan dana yang tepat sasaran oleh peserta didik penerima dana PIP, dan pelaksanaan PIP dilakukan secara trasnparan kepada orangtua atau masyarakat.

4. Evaluasi Produk Program Indonesia Pintar.

Dari sisi produk pelaksanaan PIP di SMP Negeri 7 Salatiga yang sudah dapat membantu peserta didik dalam memenuhi kebutuhan pendidikannya, dan meningkatkan akses pendidikan yang merata bagi peserta didik yang kurang mampu, serta meningkatkan rasa antusias peserta didik ke sekolah. Dampak yang dirasakan adalah peserta didik menjadi lebih percaya diri dan semangat ke sekolah. Berdasarkan hasil wawancara peserta didik lebih percaya diri ketika penerimaan raport karena administrasi di sekolah sudah lunas.

5. Analisis Manfaat dan Biaya Program Indonesia Pintar.

Berdasarkan penelitian yang dilakukan, dana PIP sangat memberikan manfaat pihak sekolah secara khusus bagi peserta didik yang berasal dari keluarga kurang 
mampu. Dengan adanya dana PIP, peserta didik dapat membeli sepatu, tas, buku, dan melunasi tunggakan yang ada di sekolah. Dana yang diterima setiap tahun sebesar 750.000,00, dana tersebut dianggap masih kurang karena kebutuhan peserta didik sangat banyak dalam satu tahun.

\section{Pembahasan}

Hasil penelitian yang telah diuraikan di atas menunjukkan bahwa desain pelaksanaan PIP di SMP negeri 7 Salatiga sudah dirancang berdasarkan tujuan yang ada di dalam petunjuk teknis PIP. Adapun tujuannya yaitu: 1) meningkatkan akses pendidikan agar semua peserta didik mendapatkan layanan pendidikan yang merata, 2) mencegah peserta didik agar tidak putus sekolah akibat kesulitan ekonomi. Tujuan yang hendak dicapai dalam pelaksanaan PIP di SMP Negeri 7 belum mencakup empat tujuan dalam PIP, namun secara garis besar sudah sesuai dengan tujuan secara nasional. PIP merupakan program yang sangat dibutuhkan oleh sekolah mengingat sebagian besar peserta didik di SMP Negeri 7 Salatiga berasal dari keluarga miskin atau kurang mampu. Pelaksanaan PIP dirancang agar dapat memenuhi kebutuhan sekolah peserta didik yang berasal dari keluarga miskin, sehingga diharapkan dana PIP yang diterima oleh setiap peserta didik dapat membantu mengurangi angka putus sekolah yang terjadi di Indonesia secara khusus di SMP Negeri 7 Salatiga. Sasaran penerima dana PIP sudah dirancang sesuai dengan Juknis bahwa pemegang KPS/KKS/KIP menjadi sasaran utama dalam melakukan pengusulan penerima dana PIP.

Dari segi instalasi sumber daya manusia telah ditetapkan berdasarkan kemampuannya masing-masing, sehingga diharapkan dapat membantu pelaksanaan PIP dalam mencapai tujuan. Sarana dan prasarana yang disiapkan diharapkan dapat membantu pelaksanaan PIP berjalan dengan baik. Temuan di atas sejalan dengan hasil penelitian yang dilakukan oleh Sulhan dan Sasongko (2017) yang menjelaskan bahwa tujuan dari Program KIP adalah menghilangkan hambatan peserta didik secara ekonomi untuk berpartisipasi di sekolah sehingga dapat memperoleh akses layanan pendidikan yang lebih baik di tingkat dasar dan menengah, mencegah anak/peserta didik putus sekolah akibat kesulitan ekonomi dan menarik anak yang putus sekolah agar kembali ke sekolah, serta membantu peserta didik memenuhi kebutuhan kegiatan pembelajaran di sekolah.

Proses pelaksanaan PIP di SMP Negeri 7 Salatiga sudah berjalan sesuai dengan yang diharapkan. Prosedur pelaksanaan PIP terdiri dari 6 tahapan yaitu tahap pengusulan, penetapan penerima, sosialiasi kepada orangtua, penyaluran dana/pencairan dana, pengambilan dana secara tunai oleh peserta didik, dan monitoring pelaksanaan PIP. Pelaksanaan PIP dilaksanakan berdasarkan Juknis dapat membantu sekolah dalam meningkatkan layanan pendidikan secara khusus bagi peserta didik yang kurang mampu. Namun demikian pelaksanaan PIP belum dapat menarik peserta didik yang putus sekolah untuk kembali bersekolah, karena dana yang diterima peserta didik sangat terbatas, selain itu dana PIP diterima secara tunai oleh peserta didik, sehingga pihak sekolah terkendala melakukan pengawasan terhadap pemanfaatan dana PIP yang sudah diterima melalui Lembaga penyalur. Hasil penelitian diatas sejalan dengan penelitian Widodo (2016) yang menyatakan bahwa proses pelaksanaan PIP dilaksanakan berdasarkan 6 indikator yaitu sosialisasi PIP kepada orangtua, prosedur pelaksanaan, tahap pengajuan, penetapan penerima, tahap pencairan dan monitoring evaluasi PIP, sehingga pelaksanaan PIP berjalan dengan baik dalam mendukung layanan pendidikan di sekolah.

Faktor pendukung dalam pelaksanaan PIP antara lain adalah: orangtua antusias dalam membantu tim pelaksana melengkapi dokumen 
yang harus dipersiapkan pada saat proses pengusulan, sosialisasi bagi peserta didik dan orangtua penerima PIP yang transparan, koordinasi yang baik antar tim pelaksana PIP. Sedangkan faktor penghambat pelaksanaan PIP yaitu penyaluran dana sering terlambat sehingga tidak dapat memenuhi kebutuhan peserta didik secara berkesinambungan, Tim pelaksana kesulitan memonitoring penggunaan dana karena langsung diterima secara tunai oleh peserta didik, banyak penerima PIP yang sudah tidak sekolah atau sudah lulus dari SMP Negeri 7 Salatiga. Meskipun pelaksanaan PIP sudah sesuai dengan mekanisme pelaksanaan dalam Juknis, namun masih terdapat berbagai kendala dalam mencapai tujuan sehingga proses pelaksanaan masih terus diperbaiki. Temuan diatas sejalan dengan hasil penelitian Arbainah (2017) yang menyatakan bahwa pelaksanaan PIP belum dapat mencapai tujuan secara efektif dan efisien, sehingga masih perlu dilakukan perbaikan terus menerus oleh dinas pendidikan dan pihak sekolah. Dengan demikian, dapat dipahami bahwa pelaksanaan PIP secara menyeluruh masih memiliki kendala. Agar dapat terlaksana dengan baik dan tujuannya dapat tercapai secara menyeluruh, maka pemerintah sebagai pelaksana harus rutin melakukan monitoring kepada setiap sekolah yang menerima dana PIP.

Produk atau hasil yang diperoleh dari pelaksanaan PIP di SMP Negeri 7 Salatiga belum dicapai secara maksimal berdasarkan tujuan yang ada dalam Juknis PIP. Meskipun demikian, pelaksanaan PIP telah memberikan dampak bagi peserta didik karena dapat membantu meningkatkan akses pendidikan dan memperoleh layanan pendidikan sampai tamat, sehingga program tersebut dapat mencegah peserta didik putus sekolah karena keterbatasan ekonomi. Faktor ekonomi merupakan salah satu penghambat bagi peserta didik dalam menumpuh pendidikan hingga tamat. Hal ini sejalan dengan pendapat Zahidy (2008) bahwa penghasilan keluarga yang rendah mengakibatkan daya beli rendah sehingga sekolah dipersepsikan menjadi suatu pengeluaran, sehingga berapapun biaya yang dibutuhkan dalam membeli seragam sekolah, buku-buku, iuran, ongkos, buku, biaya fotokopi, dianggap sebagai sesuatu yang sangat memberatkan. Berdasarkan pendapat tersebut dapat diketahui bahwa kondisi ekonomi dapat menjadi penghambat bagi peserta didik yang kurang mampu untuk terus melanjutkan pendidikan. Oleh karena itu pemerintah harus terus berpartisipasi lewat program PIP yang sudah terlaksana dengan baik, sehingga hal tersebut dapat meminimalkan angka putus sekolah di Indonesia khususnya di SMP Negeri 7 Salatiga.

Pelaksanaan PIP memberikan dampak yang besar bagi peserta didik yang menerima dana PIP di SMP Negeri 7 Salatiga. Melalui program PIP banyak peserta didik yang merasakan dampak positif, karena biaya yang diterima setiap tahun dapat digunakan untuk membeli kebutuhan sekolah seperti membeli sepatu, buku tulis, seragam sekolah, dan mentupi kekurangan biaya SPP. Selain itu peserta didik penerima dana PIP menjadi percaya diri saat menerima raport karena tidak ada tunggakan biaya sekolah. Hal tersebut tentu menjadi motivasi bagi peserta didik untuk terus melanjutkan pendidikan. Dampak dari penggunaan dana PIP sudah dirasakan oleh peserta didik, pihak sekolah terus berharap program PIP terus belanjut sehingga semua peserta didik yang kurang mampu di SMP Negeri 7 Salatiga mendapatkan kesempatan yang sama dalam menempuh pendidikan. Temuan di atas sejalan dengan hasil penelitian yang dilakukan oleh Arbainah (2017) bahwa Program Indonesia Pintar sangat membantu memenuhi kebutuhan sekolah peserta didik, mulai dari membeli buku dan perlengkapan sekolah lainnya. Selain itu respon orangtua sangat positif karena dapat membantu mengatasi keterbatasan ekonomi keluarga. Dapat dipahami bahwa pelaksanaan Program 
Indonesia Pintar telah memberikan dampak yang baik bagi seluruh peserta didik yang menerima dana PIP di SMP Negeri 7 Salatiga.

\section{SIMPULAN DAN SARAN \\ Simpulan}

Hasil evaluasi di atas menunjukkan bahwa, pada evaluasi desain, terdapat kesenjangan antara tujuan pelaksanaan PIP di SMP Negeri 7 Salatiga dengan Juknis pelaksanaan PIP dari pemerintah.

Dari segi instalasi tidak terdapat kesenjangan antara rancangan PIP di SMP Negeri 7 Salatiga dengan Juknis pelaksanaan PIP dari pemerintah. Proses pelaksanaan didesain sesuai dengan mekanisme pelaksanaan PIP dalam Permendikbud. Pihak sekolah membentuk Tim pelaksana guna mempermudah pelaksanaan PIP.

Dari segi proses masih terdapat kesenjangan antar desain dengan pelaksanaan akibat berbagai kendala seperti penyaluran dana yang sering terlambat, kesulitan Tim pelaksana memonitoring penggunaan dana yang diterima tunai oleh peserta didik, banyak penerima PIP yang sudah tidak sekolah atau sudah lulus sedangkan dananya harus dikembalikan ke pemerintah, sehingga tidak bisa digunakan untuk membantu peserta didik yang lebih membutuhkan.

Dari segi produk juga masih terdapat kesenjangan dalam pelaksanaan PIP di SMP Negeri 7 Salatiga karena dana yang diterima masih kurang, sehingga belum mampu memenuhi kebutuhan sekolah sesuai dengan Juknis.

Dari segi Analisis Manfaat dan Biaya juga masih terdapat kesenjangan karena walaupuan peserta didik penerima PIP merasakan manfaat dari Program Indonesia Pintar yang dilaksanakan di SMP Negeri 7 Salatiga. namun dana yang diterima setiap tahun masih sangat kurang dan belum mampu memenuhi seluruh kebutuhan peserta didik sesuai dengan manfaat yang ingin dicapai pemerintah dalam Juknis.

\section{Saran}

Terdapat beberapa saran yang peneliti sampaikan guna perbaikan pelaksanaan Program Indonesia Pintar pada tahun berikutnya, sebagai berikut.

1. Bagi Sekolah. Sekolah harus lebih intensif dalam menjalin kerjasama dengan pihak lain (Komite sekolah dan orangtua). Disamping itu Sekolah juga harus lebih tegas dalam mengumpulkan kwitansi pembelian kebutuhan sekolah, sehingga penggunaan dana PIP tepat sasaran.

2. Bagi Orangtua. Orangtua harus mendukung anak dalam mengumpulkan kwitansi pembelian barang dari dana PIP, serta mendukung anak untuk memanfaatkan dana PIP sebagaimana mestinya.

3. Bagi Dinas Pendidikan. Dinas Pendidikan perlu melakukan monitoring dan evaluasi terhadap pelaksanaan PIP di sekolah-sekolah yang melaksanaan, khususnya di SMP Negeri 7 Salatiga, agar Dinas Pendidikan dapat mengambil kebijakan berupa perbaikan terhadap pelaksanaan PIP di masa yang akan datang.

4. Bagi BAPPENAS, Kemenkeu, dan Kemendikbud. Program Indonesia Pintar hendaknya dilanjutkan dengan mempertimbangkan ulang pemberian dana secara tunai oleh penerima guna menghindari penyelewengan dana oleh orangtua peserta PIP.

\section{DAFTAR PUSTAKA}

Arbainah. (2017). Evaluasi Program Indonesia Pintar di Desa Tajur Kecamatan Long Ikis Kabupaten Paser. Jurnal Administrasi Negeri, Vol. 5, No. 4, hal: $10-12$

Astuti Septiani Rini. (2016). Implementasi Kebijakan Kartu Indonesia Pintar dalam Upaya Pemerataan Pendidikan 
Tahun Ajaran 2015/2016 di SMP

Negeri 1 Semin. Universitas Negeri Yogyakarta.

Arikunto. S \& Jabar. C.S.A., (2010). Evaluasi Program Pendidikan: Pedoman

Teoritis Praktis Bagi Mahasiswa dan Praktisi Pendidikan. Jakarta: Bumi Aksara.

Badan Pusat Statistik. (2017). Tingkat Kemiskinan. Salatiga: Pemda Kota Salatiga.

Boulmetis, J. \& Phyllis Dutwin. 2017. The ABCs of Evaluation: Timeless Techniques for Program and Project Managers, second edition. Market street, San Francisco: Jossey Bass A Wiley Imprint.

Depdiknas. (2005). Rencana Pembangunan Pendidikan Nasional Jangka Menengah Tahun 2005-2009. Menteri Pendidikan Nasional. Jakarta: Depdiknas.

Departemen Pendidikan Nasional. (2003). Undang Undang No. 20 Tahun 2003 tentang Sistem Pendidikan Nasional. Jakarta: Depdiknas.

Mulyatiningsih, E. (2011). Evaluasi Proses Suatu Program. Bumi Aksara. Jakarta

Kemendikbud. (2014). Rencana Pembangunan Jangka Menengah Nasional 2015-2019. Jakarta: Kemendikbud.

Kemendikbud. (2015). Rencana Strategis Kementerian Pendidikan dan Kebudayaan Tahun 2015 - 2019. Biro
Perencanaan dan Kerjasama Luar Negeri: Kemendikbud.

Kemendikbud. (2015). Peraturan Menteri Pendidikan dan Kebudayaan Nomor 12 Tahun 2015. Petunjuk Teknis Program Indonesia Pintar. Jakarta: Kemendikbud.

Santoso, H.M., Sarjono.Y., Wafroturrohmah. (2014). Pengelolaan Bantuan Siswa Miskin di SMP Muhammadiyah 8 Wonogiri. Jurnal Pendidikan Ilmu Sosial, Vol. 24, No. 2, hal: 35-44.

Sulhan M. \& Sasongko Totok. (2017). Implementasi Kebijkan Program Penanggulangan Kemiskinan Melalui Kartu Penjamin Sosial dan Kartu Indonesia Pintar Pada Masyarakat (Studi Kasus di Kelurahan Kauman). Jurnal Ilmu Sosial dan Ilmu Politik. Vol. 6 No. 1, hal: 15-18.

Walikota Salatiga. 2016. Peraturan Walikota Salatiga Nomor 10 Tahun 2016 tentang Rencana Kerja Pemerintah Daerah (RKPD) Tahun 2017. Salatiga: Pemerintah Kota Salatiga.

Widodo, Budi. (2016). Evaluasi Pemanfaatan Program Indonesia Pintar di SMK Cokroaminoto Pandak. Skripsi. Universitas Negeri Yogyakarta.

Zahidy Budhi Achmad. (2008). Perluasan Akses Pelayanan Pendidikan di SMP (Kecamatan Bumijaya Kabupaten Tegal). Tesis. Universitas Diponegoro. Semarang. 